\title{
Fetomaternal outcome in pregnancy with HELLP syndrome
}

\author{
Prachi M. Shelat*, Rupa C. Vyas, Sapana R. Shah, Naimish D. Nathwani
}

Department of Obstetrics and Gynecology, Smt. N. H. L. Municipal Medical College, Ellisbridge, Ahmedabad, Gujarat, India

Received: 22 April 2020

Accepted: 29 May 2020

\section{*Correspondence:}

Dr. Prachi M. Shelat,

E-mail: pitushelat@gmail.com

Copyright: (C) the author(s), publisher and licensee Medip Academy. This is an open-access article distributed under the terms of the Creative Commons Attribution Non-Commercial License, which permits unrestricted non-commercial use, distribution, and reproduction in any medium, provided the original work is properly cited.

\section{ABSTRACT}

Background: HELLP Syndrome is a serious complication of pregnancy induced hypertensive disorders. It is defined as a triad of hemolysis, elevated liver enzymes, and low platelet count (HELLP). Objectives of this study was to find out incidence of HELLP syndrome in pre-eclampsia, eclampsia and its overall incidence. To analyse the clinical profile of HELLP syndrome. To study maternal and perinatal outcome including morbidity and mortality.

Methods: A retrospective study was conducted from July 2017 to September 2019 at a tertiary care center with inclusion criteria of abnormal peripheral blood smear, elevated liver enzymes (LDH, aspartate aminotransferase), and low platelet count.

Results: HELLP syndrome was more common in younger age group (45\%) and in primigravida (52.5\%). Most of the patients presented at $>36$ weeks of gestation $(40 \%)$ and most of the patients delivered by caesarean section $(67.5 \%)$. Maternal complications were acute renal failure $(27.5 \%)$, DIC $(22.5 \%)$, maternal mortality $(7.5 \%)$. Neonatal complications associated were intrauterine death $(27.5 \%)$, prematurity $(25 \%)$ and intrauterine growth retardation $(15 \%)$.

Conclusions: Thus, HELLP syndrome requires an early diagnosis and early initiation of treatment at tertiary care center with all the medical facilities available.

Keywords: Elevated liver enzymes, Hemolysis, Low platelets, Thrombocytopenia

\section{INTRODUCTION}

Hypertension in pregnancy is defined as systolic blood pressure level of $140 \mathrm{mmHg}$ or higher and/or diastolic blood pressure of $90 \mathrm{mmHg}$ or higher. Hypertensive disorders during pregnancy are further included into 4 well defined groups:

- Gestational hypertension

- Preeclampsia, eclampsia

- Chronic hypertension

- Preeclampsia superimposed to chronic hypertension

Preeclampsia is characterized by de novo development of hypertension and proteinuria after 20 weeks of gestation.
HELLP syndrome is a severe form of Preeclampsia characterized by

- Hemolysis

- Elevated liver enzymes

- Low platelet count

A pregnancy with previous history of HELLP syndrome has higher chances of HELLP syndrome or pre-eclampsia in present pregnancy which indicates multiple gene variants with contributing effects of maternal and environmental factors.

The pathophysiology of HELLP syndrome is ill-defined and induction of the delivery is the only specific therapy. 
Placenta plays main role in occurrence of HELLP Syndrome. Incomplete trophoblastic invasion of spiral arteries with release of anti-angiogenic factor like sFlt1 into maternal blood and activation of the coagulation in micro vessels results in consumption of platelet and hemolysis in micro-vessels. Placental FAS ligand leads to hepatocyte damage, periportal necrosis. ${ }^{1-6}$ Activation of coagulation system and platelet precipitate which results in disseminated intravascular coagulation (DIC).

Soluble vascular endothelial growth factor receptor-1 (Svegfr-1) released by hypoxic placenta binds to VEGF and PGF causing endothelial cell and placental dysfunction which leads to hypertension, proteinuria and increased platelet activation and aggregation. ${ }^{7}$ Another theory suggests a placental-instigated acute inflammatory condition targeting the liver. ${ }^{8}$ In addition, dysfunction in the complement system via excessive activation or defective regulation for a given amount of endothelial injury has been proposed to cause damage to hepatic vessels in HELLP. ${ }^{9}$ Thus, many hypotheses have been established to define pathogenesis of HELLP syndrome, but the true pathology remains a mystery.

Prevalence ranges from $0.2 \%$ to $0.6 \%$ in all pregnancies and in $10 \%$ to $20 \%$ in patients with preeclampsia. It typically occurs between 27 weeks of gestation and delivery and immediate postpartum in $15 \%$ to $30 \%$ of cases. $^{10}$

Risk factors include primigravida, overweight, previous history of preeclampsia, white race, history of HELLP in previous pregnancy, maternal age $>35$ years, history of poor pregnancy outcome chronic hypertension. ${ }^{11-13}$ Fetal complications likely to develop are prematurity, intrauterine growth retardation, IUD, RDS.

Maternal complications are DIC, bleeding, abruption, $\mathrm{PPH}$, eclampsia, pulmonary edema, respiratory failure, adult respiratory distress syndrome (ARDS), cardiac arrest, myocardial ischemia, cerebral edema, seizures, central venous thrombosis, cerebral hemorrhage, hepatic hematoma, ascites and infection. Maternal mortality occurs by cerebral hemorrhage or stroke $(26 \%)$.

Immediate delivery is the primary choice at 34 weeks' gestation or later. At 27 to 34 weeks of gestation, corticosteroid treatment delivery is preferred. Conservative management for more than 48 to 72 hours is considered in women before 27 weeks of gestation. In cases of sever preeclampsia before 24 weeks of gestation, termination of pregnancy is seriously considered to prevent severe maternal morbidity and mortality. ${ }^{10,14,15}$

\section{METHODS}

A retrospective study was conducted from July 2017 to September 2019 at a tertiary care center. 40 patients with HELLP syndrome in pregnancy were studied for feto- maternal outcome. Informed consent was taken from all the patients.

Detailed history was taken including age, gestational age, history of poor pregnancy outcome, history of HELLP syndrome or preeclampsia in previous pregnancy.

Detailed examination done. Various investigations done include complete blood count with peripheral smear, coagulation profile with D-Dimer, LDH level, bilirubin level, fibrinogen level, serum AST/ALT level.

Various parameters noted were requirement of transfusion of blood components, mode of delivery, maternal and neonatal complications, neonatal intensive care admission.

\section{Inclusion criteria}

Diagnosis of HELLP syndrome in patients treated for preeclampsia and eclampsia confirmed by presence of microangiopathic hemolytic anemia, elevated liver enzymes and thrombocytopenia, according to following criteria:

\section{Evidence of intravascular hemolysis}

Decreasing hemoglobin with at least one of the following;

- Abnormal peripheral blood smear(schistocytes)

- Elevated lactate dehydrogenase (LDH) greater than $600 \mathrm{IU} / \mathrm{L}$

- Elevated total bilirubin equal or greater than 1.2 $\mathrm{mg} / \mathrm{dL}$.

\section{Elevated liver enzymes}

- Aspartate aminotransferase greater than $70 \mathrm{IU} / \mathrm{L}$

- LDH greater than $600 \mathrm{IU} / \mathrm{L}$.

Low platelet count

- Platelet count lower than 1,00,000/uL.

\section{Diagnostic criteria}

There are two definitions for diagnosing HELLP syndrome

Tennessee classification of HELLP syndrome

Characteristics of complete HELLP syndrome are as following

- Platelet count of $1,00,000 / \mathrm{uL}$ or less

- $\quad$ AST or ALT levels of 70 IU/L or more

- LDH levels of $600 \mathrm{IU} / \mathrm{L}$ (or bilirubin $>1.2 \mathrm{mg} / \mathrm{dL}$ ) or more (with an abnormal peripheral smear). 
Characteristics of partial HELLP syndrome are preeclampsia plus one of the following

- HEL: hemolysis, liver dysfunction, no thrombocytopenia

- ELLP: elevated liver enzyme levels, thrombocytopenia, no hemolysis

- EL: mildly elevated liver enzyme levels, no thrombocytopenia, no hemolysis

- LP: thrombocytopenia, no hemolysis, normal liver enzyme levels.

Table 1: The Mississippi classification of HELLP syndrome. ${ }^{16}$

\begin{tabular}{|llll|}
\hline \hline & $\begin{array}{l}\text { Class } 1 \\
\text { (severe) }\end{array}$ & $\begin{array}{l}\text { Class 2 } \\
\text { (moderate) }\end{array}$ & $\begin{array}{l}\text { Class 3 } \\
\text { (mild) }\end{array}$ \\
\hline Platelets & $\leq 50,000 / \mu 1$ & $\begin{array}{l}50,000- \\
1,00,000 / \mu 1\end{array}$ & $\begin{array}{l}1,00,000- \\
1,50,000 / \mu 1\end{array}$ \\
\hline $\begin{array}{l}\text { AST or } \\
\text { ALT }\end{array}$ & $\geq 70 \mathrm{IU} / \mathrm{L}$ & $\geq 70 \mathrm{IU} / \mathrm{L}$ & $\geq 40 \mathrm{IU} / \mathrm{L}$ \\
\hline $\mathrm{LDH}$ & $\geq 600 \mathrm{IU} / \mathrm{L}$ & $\geq 600 \mathrm{IU} / \mathrm{L}$ & $\geq 600 \mathrm{IU} / \mathrm{L}$ \\
\hline
\end{tabular}

\section{RESULTS}

Present study includes incidence, management and fetomaternal outcome of 40 pregnant women with HELLP syndrome at a tertiary care center during July 2017 to September 2019. Total 21, 118 women delivered during this time period. Study shows $0.19 \%$ incidence of HELLP syndrome in total deliveries and $23 \%$ incidence of HELLP syndrome in preeclampsia and eclampsia.

Among 40 patients diagnosed, 62.5\% were emergency cases and $37.5 \%$ were previously registered patients taking regular antenatal visits which shows that regular antenatal visit is must to reduce incidence of disease and control of hypertension.

Table 2: Demographic data.

\begin{tabular}{|lll|}
\hline Age (in years) & $\begin{array}{l}\text { Present study } \\
(\mathbf{n}=\mathbf{4 0}) \mathbf{N o} .(\%)\end{array}$ & $\begin{array}{l}\text { Narayan L et al } \\
(\mathbf{n}=\mathbf{1 5})\end{array}$ \\
\hline$<20$ & $5(12.5 \%)$ & $0(0 \%)$ \\
\hline $20-25$ & $18(45 \%)$ & $9(60 \%)$ \\
\hline $26-30$ & $12(30 \%)$ & $3(20 \%)$ \\
\hline$>30$ & $5(12.5 \%)$ & $3(20 \%)$ \\
\hline
\end{tabular}

Table 3: Parity and HELLP syndrome.

\begin{tabular}{|lll|}
\hline Parity & $\begin{array}{l}\text { Present study } \\
(\mathbf{n}=\mathbf{4 0}) \mathbf{N o} .(\%)\end{array}$ & $\begin{array}{l}\text { Durugkar K et al } \\
(\mathbf{n}=\mathbf{7 8}) \text { No. }(\%)\end{array}$ \\
\hline Primiparity & $21(52.5 \%)$ & $55(70.5 \%)$ \\
\hline Multiparity & $19(47.5 \%)$ & $23(29.5 \%)$ \\
\hline
\end{tabular}

Table 4: Mode of delivery.

\begin{tabular}{|c|c|c|c|}
\hline Mode of delivery & $\begin{array}{l}\text { Present study }(\mathrm{n}=40) \text { No. } \\
(\%)\end{array}$ & $\begin{array}{l}\text { Kaur AP et al }{ }^{19}(\mathrm{n}=71) \text { No. } \\
(\%)\end{array}$ & $\begin{array}{l}\text { George P et } a^{20}(\mathbf{n}=55) \text { No. } \\
(\%)\end{array}$ \\
\hline Vaginal & $13(32.5 \%)$ & $30(42.2 \%)$ & $14(25.4 \%)$ \\
\hline LSCS & $27(67.5 \%)$ & $41(57.8)$ & $41(74.5 \%)$ \\
\hline
\end{tabular}

Table 5: Neonatal complications.

\begin{tabular}{|c|c|c|c|}
\hline Complications & $\begin{array}{l}\text { Present study }(\mathrm{n}=\mathbf{4 0}) \\
\text { No. }(\%)\end{array}$ & $\begin{array}{l}\text { Kaur AP et } a^{19}(n=71) \text { No. } \\
(\%)\end{array}$ & $\begin{array}{l}\text { Durugkar K et al }{ }^{18}(\mathrm{n}=78) \text { No. } \\
(\%)\end{array}$ \\
\hline Prematurity & $10(25 \%)$ & $19(26.8 \%)$ & $48(61.5 \%)$ \\
\hline RDS & $8(20 \%)$ & $23(32.4 \%)$ & $4(5.1 \%)$ \\
\hline IUGR & $6(15 \%)$ & $25(35.2 \%)$ & $13(16.7 \%)$ \\
\hline IUD & $11(27.5 \%)$ & $23(32.4 \%)$ & $10(12.8 \%)$ \\
\hline Neonatal death & $3(7.5 \%)$ & $8(11.3 \%)$ & $17(21.8 \%)$ \\
\hline
\end{tabular}

Table 6: Requirement of blood component transfusion in HELLP syndrome in various studies.

\begin{tabular}{|llll|}
\hline & Present study & Imir GA & de Gracia VP \\
\hline Transfusion required & $82.5 \%$ & $62.5 \%$ & $29 \%$ \\
\hline
\end{tabular}

Table 7: Maternal complications.

\begin{tabular}{|llll|}
\hline Complications & $\begin{array}{l}\text { Present study }(\mathbf{n}=\mathbf{4 0}) \\
\text { No. }(\%)\end{array}$ & $\begin{array}{l}\text { Durugkar K et al } \\
\text { No. }(\%)\end{array}$ & $\left.\begin{array}{l}\text { Kaur AP et al } \\
(\mathbf{1 9}(\mathbf{\%}=71)\end{array}\right)$ \\
\hline Placental abruption & $5(12.5 \%)$ & $11(14.1 \%)$ & $3(4.2 \%)$ \\
\hline DIC & $9(22.5 \%)$ & $11(14.1 \%)$ & $4(5.4 \%)$ \\
\hline Eclampsia & $6(15 \%)$ & $10(12.8 \%)$ & $15(21.1 \%)$ \\
\hline
\end{tabular}




\begin{tabular}{|llll|}
\hline Complications & $\begin{array}{l}\text { Present study }(\mathbf{n}=\mathbf{4 0}) \\
\text { No. }(\%)\end{array}$ & $\begin{array}{l}\text { Durugkar K et al } \\
\text { No. }(\mathbf{1 8})\end{array}$ & $\begin{array}{l}\text { Kaur AP et al }^{19}(\mathbf{n}=\mathbf{7 1}) \text { No. } \\
(\%)\end{array}$ \\
\hline Acute renal failure & $11(27.5 \%)$ & $1(1.3 \%)$ & $8(11.3 \%)$ \\
\hline Pulmonary oedema & $5(12.5 \%)$ & - & $7(9.9 \%)$ \\
\hline Postpartum hemorrhage & $6(15 \%)$ & $11(14.1 \%)$ & $8(11.3 \%)$ \\
\hline Multiorgan dysfunction & $3(7.5 \%)$ & $2(2.3 \%)$ & - \\
\hline Death & $3(7.5 \%)$ & $3(3.8 \%)$ & $14(19.7 \%)$ \\
\hline
\end{tabular}

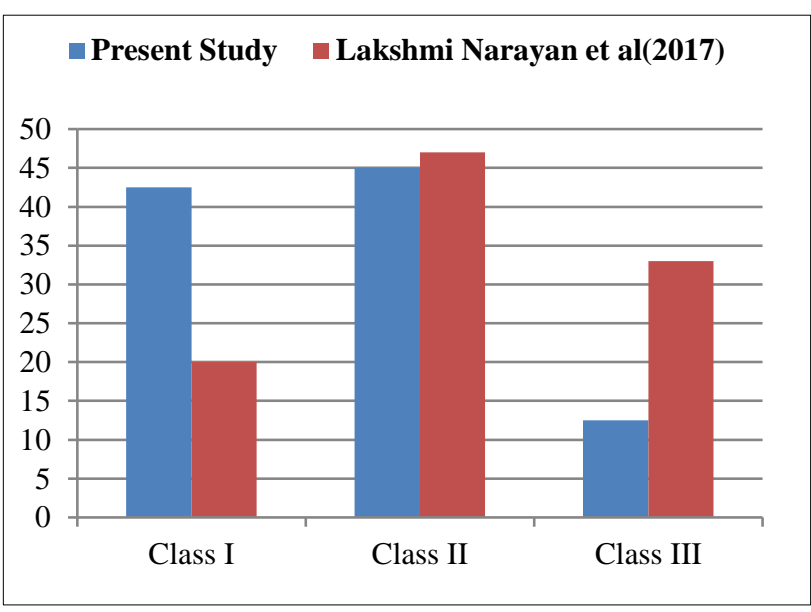

Figure 1: Distribution of cases according to Mississippi classification.

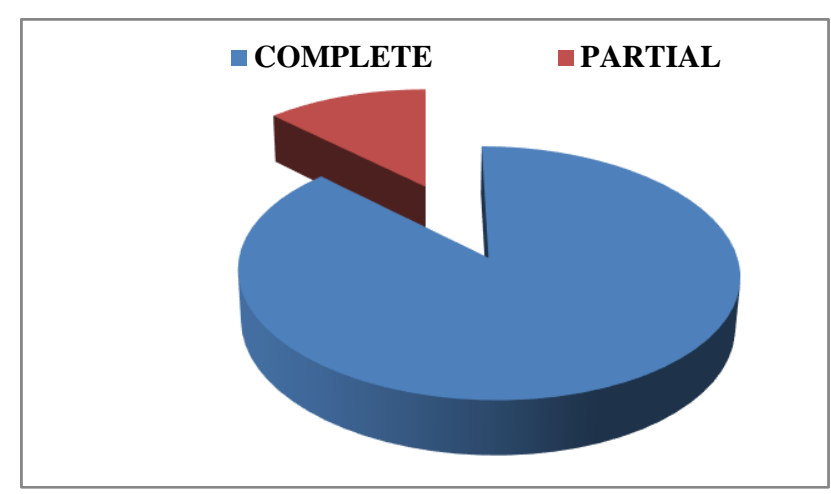

Figure 2: Distribution of cases according to Tenessee classification system.

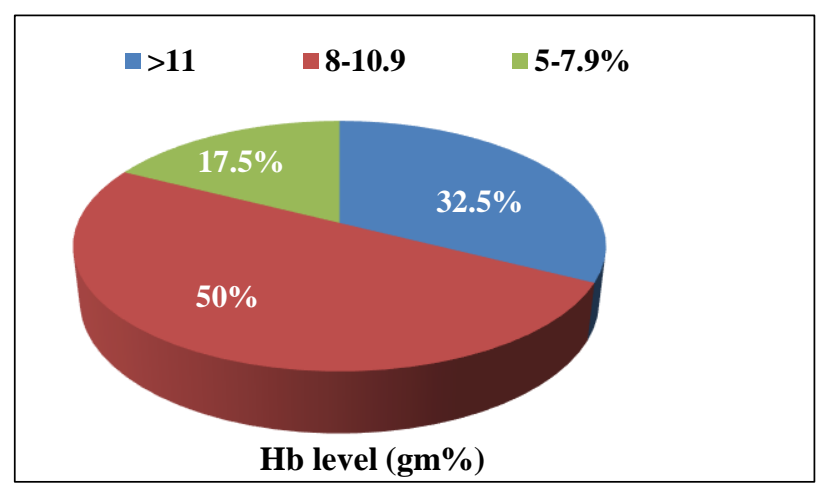

Figure 3: Haemoglobin level in patients with HELLP syndrome in present study.

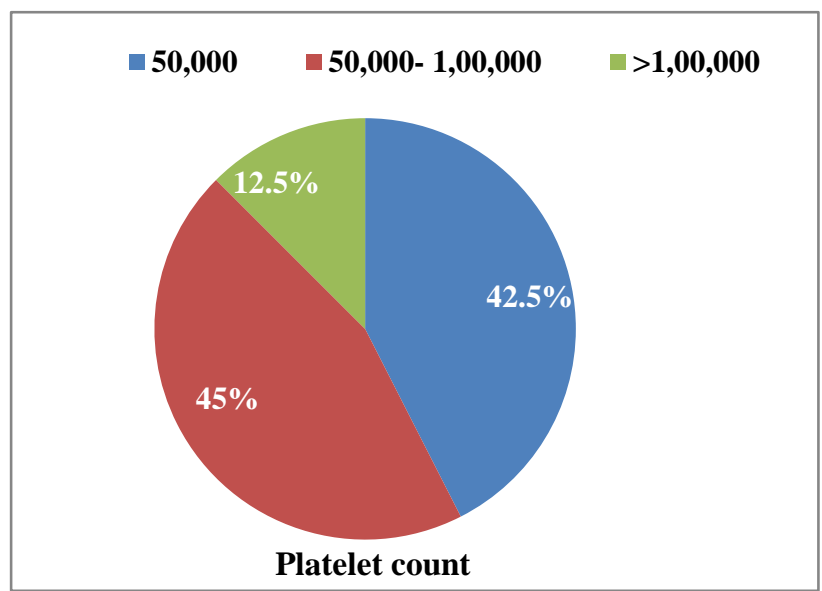

Figure 4: Platelet counts in patients with HELLP syndrome.

\section{DISCUSSION}

HELLP syndrome is a serious complication of pregnancy associated with increased maternal morbidity and mortality. The purpose of screening and management of HELLP syndrome is to prevent intrauterine death, eclampsia, acute renal failure, DIC, and decrease incidence of maternal and perinatal morbidity and mortality. The result of the present study shows that $62.5 \%$ of patients were unregistered and it was more common in 20-25 years age group accounting $45 \%$ compared to Narayan L et al, which showed $60 \%$ (Table 2). ${ }^{17}$ Primigravida patients have more chances to develop this disease and mean gestational age at the time of diagnosis was 36 weeks (Table 3 ).

In this study, most cases were falling into class II of Mississippi classification (45\%) (Figure 1) and $87.5 \%$ cases were of complete HELLP syndrome according to Tenessee classification (Figure 2). 13 had vaginal deliveries and 27 patients underwent LSCS thus caesarean section being most common mode of termination in HELLP syndrome (Table 4).

Intrauterine death and prematurity were most common complications associated with this study whereas study by Kaur AP et al, had IUGR (35.2\%) and prematurity $(61.5 \%)$ as the most common neonatal complications subsequently.19 Perinatal death occurred in 3 cases (7.5\%) (Table 5). 
Most common complication in this study were acute renal failure $(27.5 \%)$ and DIC $(22.5 \%)$. Study by Durugkar K et al and Kaur AP et al showed most common complications to be of DIC (14.1\%) and eclampsia $(21.1 \%)$ subsequently (Table 7). ${ }^{18,19}$

Out of 11 patients with ARF 3 required hemodialysis. Patients with DIC required PCV, FFP, PRC, cryoprecipitate transfusions. All the patients with $\mathrm{PPH}$ were managed conservatively with uterotonics and blood transfusions. As $67.5 \%$ patients in this study were belonged to lower socio-economic class and anemic (Figure 3 ) and $87.5 \%$ patients had platelet count less than 1, 00,000 (Figure 4) so blood and blood component requirements is higher in this study (Table 6).

All the patients with eclampsia were given full dose $\mathrm{MgSO} 4$ and after stabilization they had undergone induction of labour. Patients with pulmonary edema and MODS required ICU admission and ventilator support. Maternal mortality occurred in 3 cases $(7.5 \%)$ showing HELLP syndrome to be a very fatal disease in pregnancy (Table 7).

\section{CONCLUSION}

The result of present study shows that HELLP syndrome considerably affects the maternal and perinatal outcome in pregnancy. It has a very unpredictable course and outcome. It needs to be diagnosed as early as possible. The study suggests that all patients with hypertension should be screened and should have a complete blood count, platelet count and liver function tests.

Once diagnosis of HELLP syndrome has been made, it warrants aggressive intervention with control of blood pressure, anti-seizure prophylaxis, corticosteroid treatment for fetal lung maturity and expeditious delivery. In this study most of the patients required blood component transfusions and patients with organ failure required ICU support and/or haemodialysis. So, patients diagnosed with HELLP syndrome should be managed at a tertiary care centre where all medical facilities are available. Thus, an early diagnosis and early initiation of treatment significantly helps in improving maternal morbidity and mortality of patients with HELLP syndrome.

Funding: No funding sources Conflict of interest: None declared

Ethical approval: The study was approved by the Institutional Ethics Committee

\section{REFERENCES}

1. Litchman, M, Kipps T, Seligsohn U, Kaushansky K, Prchal J. Thrombocytopenia. Williams Hematology, Eighth Edition. Mcgraw-Hill Companies; 2010:119.

2. Knerr I, Beinder E, Rascher W. Syncytin, a novel human endogenous retroviral gene in human placenta: Evidence for its dysregulation in preeclampsia and HELLP syndrome. Am J Obstet Gynecol. 2002;186:210.

3. Levine RJ, Maynard SE, Qian C, Lim KH, England $\mathrm{LJ}, \mathrm{Yu} \mathrm{KF}$, et al. Circulating angiogenic factors and the risk of preeclampsia. $\mathrm{N}$ Engl $\mathrm{J}$ Med. 2004;350:672.

4. Mutter WP, Karumanchi SA. Molecular mechanism of preeclampsia. Microvasc Res. 2008;75:1.

5. Widmer M, Villar J, Benigni A, Conde-Agudelo A, Karumanchi SA, Lindheimer M. Mapping the theories of preeclampsia and the role of angiogenic factors: a systematic review. Obstet Gynecol. 2007;109(1):168-80.

6. Semenovskaya Z, Erogul M. Pregnancy, preeclampsia. Medscape Reference; 2011.

7. Zhou Y, McMaster M, Woo K, Janatpour M, Perry J, Karpanen T, et al. Vascular endothelial growth factor ligands and receptors that regulate human cytotrophoblast survival are dysregulated in severe preeclampsia and hemolysis, elevated liver enzymes and low platelets syndrome. Am J Pathol. 2002; 160:1405-23.

8. Strand S, Strand D. Placenta-derived CD59 ligand causes liver damage in haemolysis, elevated liver enzymes and low platelet count syndrome. Gastroenterol. 2004;126:849-58.

9. Fang C, Richards A, Liszewski MK, Kavanagh D, Atkinson JP. Advances in understanding in pathogenesis of aHUS and HELLP. BJH British J Hematol. 2008;143:336-48.

10. Sibai BM. The HELLP syndrome (hemolysis, elevated liver enzymes and low platelets): much ado about nothing? Am J Obstet Gynecol. 1990;162:3116.

11. Chhabra S, Qureshi A, Datta N. Prevalence of HELLP syndrome in gestational hypertension in India. J Obstet Gynecol. 2006;26(6):531-3.

12. Rahman TM, Wendon J. Severe hepatic dysfunction in pregnancy. Q J Med. 2002;95:343.

13. Padden MO. HELLP syndrome: recognition and perinatal management. Am Family Phys. 1999;60(3):829.

14. Harms K, Rath W, Herting E, Kuhn W. Maternal hemolysis, elevated liver enzymes, low platelet count and neonatal outcome. Am J Perinatol. 1995;12:93.

15. Sibai BM. Diagnosis, controversies, and management of the syndrome of hemolysis, elevated liver enzymes, and low platelet count. Am J Obstet Gynecol. 2004;103:981-91.

16. Martin JN, Magann EF, Blake PG. Analysis of 454 pregnancies with severe preeclampsia, eclampsia, HELLP syndrome using the 3class system of classification. Am J Gynecol. 1993;168:386.

17. Lakshmi NK, Kavitha G, Prabha Devi K, Gayathri KB. Study on HELLP syndrome-maternal and perinatal outcome. Int J Reprod Contracept Obstet Gynecol. 2017;6:714-9.

18. Durugkar K, Bal H, Agrawal S. A study of maternal and perinatal outcome in cases of HELLP and partial 
HELLP syndrome. Int J Reprod Contracept Obstet Gynecol. 2017;6:5491-6.

19. Kaur AP, Kaur N, Dhillon SPS. HELLP syndrome and its implications on maternal and perinatal outcome. Int $\mathbf{J}$ Reprod Contracept Obstet Gynecol. 2018;7:1007-11.

20. George P, Thankachi VJ. Hellp syndrome-a study from a tertiary centre in India. J Contemp Med Res. 2017;4(7):1604-6.

21. İmir GA, Kol Öİ, Kaygusuz K, Çetin A, Çetin M, Güvenal T, Gönüllü M. Perinatal outcomes in
HELLP syndrome. J Turkish-German Gynecol Associ. 2008;9(2):89-93.

22. Vigil P, Gracia D. Pregnancy complicated by preeclampsia, eclampsia with HELLP Syndrome. Inte J Gynecol Obstet. 2001;72:17-23.

Cite this article as: Shelat PM, Vyas RC, Shah SR, Nathwani ND. Fetomaternal outcome in pregnancy with HELLP syndrome. Int J Reprod Contracept Obstet Gynecol 2020;9:2860-5. 